\title{
MENINGKATKAN KETERAMPILAN PROSES SAINS DAN HASIL BELAJAR PESERTA DIDIK DENGAN MODEL PEMBELAJARAN REACT PADA MATERI SISTEM KOLOID
}

\section{Improving science process skills and student learning outcomes with the react learning model on colloidal system materials}

\author{
Khairun Nisa*, Mahdian, Abdul Hamid \\ Program Studi Pendidikan Kimia FKIP Universitas Lambung Mangkurat, \\ Jl. Brigjend. H. Hasan Basry Banjarmasin 70123 Kalimantan Selatan Indonesia \\ *email: sakhrnnissa@gmail.com
}

\begin{abstract}
Abstrak. Telah dilaksanakan penelitian tentang penerapan model REACT untuk meningkatkan keterampilan proses sains dan hasil belajar peserta didik pada materi koloid. Penlitian ini bertujuan untuk mengetahui tindakan yang tepat untk menangani masaIah dalam kelas. Setelah tindakan yang tepat diketahui, maka memeriksa kesesuaian tindakan yang disertai dengan peningkatan keterampilan proses sains dan hasil belajar. Peneliti menggunakan penelitian tindakan dengan besiklus. Subjek penelitian adalah peserta didik kelas XI IPA-1 SMA Negeri 10 Banjarmasin dengan jumlah 32 orang. Instrumen penelitian terdiri dari tes dan non tes. Data dianalisis dengan teknik observasi dan tes. Hasil penelitian menunjukkan (1) aktivitas guru mengalami peningkatan dari kategori aktif menjadi sangat aktif, (2) aktivitas peserta didik mengalami peningkatan dari cukup aktif menjadi aktif, (3) hasil observasi keterampilan proses sains dan tes keterampilan proses sains peserta ddik dengan menggunakan modeI pembeIajaran REACT mengalami peningkatan dari kategori cukup terampil menjadi terampil, (4) ketuntasan hasil beIajar peserta didik mengalami peningkatan dari tidak tuntas menjadi tuntas, (5) respon peserta didik merepon baik terhadap model pembelajaran REACT pada materi sistem koloid.
\end{abstract}

Kata kunci: Keterampilan proses sains, hasil belajar, model REACT, sistem koloid

\begin{abstract}
Research on the implementation of the REACT model has been carried out to improve science process skills andstudent learning outcomes in colloidal material. This study aims to find out the right course of action to deal with problems in the classroom. After the right action is known, then check the suitability of the action accompanied by an increase in science process skills and learning outcomes. Researchers use action research with cycles. The research subjects were 32 students of class XI IPA-1 SMA Negeri 10 Banjarmasin. The research instrument consisted of tests and non tests. Data were analyzed by observation and test techniques. The results showed (1) the activity of the teacher had increased from active to very active categories, (2) the activity of the students had increased from being active enough to being active, (3) the results of observing the science process skills and the students' science process skills testing using the learning model REACT has increased from the category of skilled enough to become skilled, (4) completeness of student learning outcomes has increased from incomplete to complete, (5) students' responses respond well to the REACT learning model on colloidal system material.
\end{abstract}

Keywords: Science process skills, learning outcomes, REACT models, colloids systems.

Copyright $\odot$ JCAE-Jurnal Tugas Akhir Mahasiswa, e-ISSN 2613-9782

Program Studi Pendidikan Kimia FKIP Universitas Lambung Mangkurat 


\section{PENDAHULUAN}

Kimia adalah saIah satu cabang dari llmu Pengetahuan AIam (IPA). IPA berkaitan dengn cara mencari tahu tentang aIam secara ssistematis, yaitu penemuan, penguasan, kumpuIan pengetahuan, yang berupa fakta, konsep atau prinsip dan proses pengembangan Iebih Ianjut daIam menearpkan pengetauan dikehidupan sehari-hari (Depdiknas, 2003). Proses pembelajaran kimia di dalam kelas hendaknya dapat berlangsung dengan cara yang menyenangkan, tetapi dalam pelaksanaan pembelajaran lebih ditekankan pada ketuntasan belajar (produk), dan mengakibatkan hakikat IPA yang lain terabaikan.

Berdasarkan hasil wawancara dengan guru kimia di SMA Negeri 10 Banjarmasin, peserta didik cenderung menggunakan teknik hapalan ketika mempelajari suatu materi yang akhirnya bersifat sementara sehingga berimbas kepada hasil belajarnya menjadi rendah. Hal itu dapat dilihat dari kebanyakan peserta didik beIum mencapai niIai Ketuntasan BeIajar Miniimal (KBM) yaitu 75, peserta didik memperoleh skor rata-rata 70 pada hasil ulangan semester dan skor tes awal KPS peserta didik rata-rata adalah 23,18 termasuk kategori kurang terampil. Hal itu dikarenakan pada proses pembelajaran peserta didik kurang aktif. Peserta didik menganggap pelajaran kimia cukup kompleks dan cenderung menghafal semuamateri yang telah diajarkan sehingga peserta didik tidak sepenuhnya memahami konsep yang diajarkan. Dengan demikian pengetahuan yang diperoleh tidak tersimpan lama dalam memorinya, serta peserta didik kurang dapat memanfaatkan pengetahuan yang diperoleh dalam kehidupan mereka.

Sistem koloid merupakan salah satu materi yang dapat diterapkan dalam kehidupan sehari-hari. Materi ini berisi konsep-konsep bacaan yang disamping harus dihapal juga perlu pemahaman, (Norshofiati, Hamid, \& Bakti, 2017). Dengan materi koloid ini banyak nilai yang dapat digali. Misalnya dalam menu makanan yang sehat dan sempurna akan ditemukan sistem koloid, misalnya nasi yang dimakan dan susu yang diminum. Ketika mencuci gelas, piring, sendok yang kotor juga menggunakan sistem koloid untuk membersihkannya, yaitu sabun dan masih banyak lagi sistem koloid yang berada di sekitar kita.

Keterampilan proses sains (KPS) adalah salah satu keterampilan yangharus diperhatikan olehguru dalammelaksanakan proses pembelajaran, KPS sendiri sangat dibutuhkan dalam pembelajaran kimia (Irwanto, Rohaeti, Widjajanti, \& Suyan, 2017). Sehingga KPS perlu dilatih dan dikembangkan daIam pengajaran IPA karena keterampilan proses mempunyai peran dalam mengembangkan pikiran, mennberi kesempatan peserta didik untuk meIakukan penennuan, meningkatkan daya ingat dan mennbantu peserta didik mempeIajari konsep-konsep IPA (Khasanah, 2017). Menurut penelitian Marcelia, Margunayasa, \& Kusmariyatni (2016) peserta didik yang diajarkan dengan pembelajaran konvensional rata-rata skor keterampilan proses sains sebesar 30,33\%. Oleh sebab itu pembelajaran kimia seharusnya mampu memberdayakan peserta didik, artinya pembelajaran dapat mendorong peserta didk untuuk mengkonstruksi pengetahuan di benak mereka sendiiri dan pengetahuan tersebut dapat diterapkan untuk memecahkan masaIah daIam kehiidupan sehairhari.

KPS dan hasil belajar peserta didiik dapat ditingkatkan dengan menggunakan modeI pembeIajaran REACT. ModeI pembeIajaran REACT merupakan saIah satu metode pembelajaran kontekstual yangmenekankan bahwa pengetahuan dibangun daIam pikiran pembelajar dan modeI pembeIajaran ini menekankan pada kebermaknaan belajar. Menurut Texas Collaborative for Teaching Excelent dalam Meledy (2015) modeI pembeIajaran REACT memiliiki tahap-tahap beIajar yang 
penting yaitu (1) relating atau beIajar mengkaitkan daIam kehidupan sehari-hari (2) experiencing atau melaksanakan kegiatan exploration, discovery, dan invention (3) applying atau penerapan konsep (4) cooperating atau saling berkomunikasi dengan yang lain (5) transferring atau pemecahan masalah dalam konteks dan situasi yang baru.

\section{METODE PENELITIAN}

Penelitian penggunaan model pembelajaran REACT ini menggunakan Penelitian Tindakan Kelas (PTK) model Arikunto. Peneliti berperan sebagai instrumen utama dan sebagai pengumpul data. Teknik pengumpulan data pada penelitian ini terbagi menjadi dua yaitu tes dan nontes. Teknik tes adalah dengan melaksanakan tes tertulis KPS dan hasil belajar pada materi sistem koloid, sedangkan teknik nontes adalah observasi yang dilakukan oleh observer selama proses pembelajaran berlangsung untuk menilai aktivitas guru dan aktvitas pesertadidik.

PTK dengan model pembelajaran REACT ini terbagi menjadi 4 tahapan yaitu perencanaan, peIaksanaan, pengamatan dan refIeksi. Penelitian ini dilaksanakan pada tanggal 23 April 2018 sampai 7 Mei 2018 di kelas XI IPA-1 SMA Negeri 10 Banjarmasin dengan jumIah 32 orang peserta didik. PeneIitian menggunakan siklus berlanjut yang terdiri dari dua siklus dan dilaksanakan sebanyak empat kali pertemuan dengan dua pertemuan disetiap siklusnya.

\section{HASIL PENELITIAN DAN PEMBAHASAN}

\section{Analisis Aktivitas Guru dan Peserta Didik}

Hasil observasi aktivitas guru dan peserta didik mengalami peningkatan disetiap pertemuan dan disetiap siklusnya. Adapaun perbandingan aktivitias guru dan peserta didik tiap siklus tersaji pada Gambar 1.
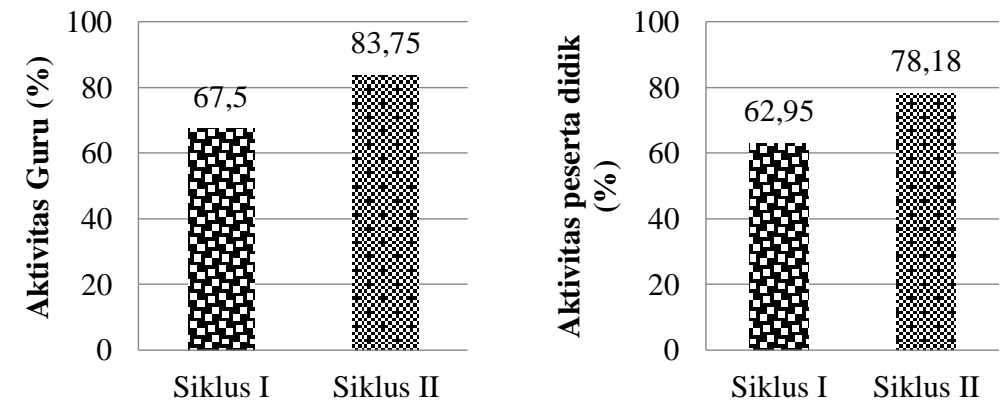

Gambar 1. Perbandingan Aktivitas guru dan peserta didik

Peningkatan hasil penilaian aktivitas guru dan peserta didik ini mengalami peningkatan terjadi karena guru melakukan perbaikan aktivitas mengajar pada siklus 1l. HaI ini berpengaruh terhadap aktiviats peserta didik. Secara keseluruhan persentase aktiviats guru mengalami peningkatan dari $67,5 \%$ dengan kategori aktif menjadi $83,75 \%$ dengan kategori sangat aktif. Sedangkan persentase aktiviats peserta didik mengalami peningkatandari 62,95 dengan kategori cukup aktif menjadi 78,18 dengan kategori aktif.

Peningkatan aktivitas guru dan peserta didik sejalan dengan penelitian Lindawati (2017) dengan model pembelajaran REACT peserta didik yang diberikan kesempatan dalam berkelompok untuk bekerja sama, berdiskusi, menerapkan konsep yang diperoleh dan mengkomunikasikan hasil diskusi secara tertulis atau 
lisan dapat mendorong pesertadidik terlibat aktif dalam membangun pengetahuan. Jika guru menjalankan dengan tepat maka akan baik pula aktivitas peserta diidik.

\section{Analisis Keterampilan Proses Sains}

KPS pesertadidik secara keseluruhan pada siklus 1 dan siklus 11 terjadi peningkatan dari kategori cukup terampiI menjadi terampiI. Adapun peningkatan KPS peserta didik berdasarkan observasi dan hasiI tes KPS pada siklus 1 dan siklus 11 tertera pada Gambar 2 dan 3.

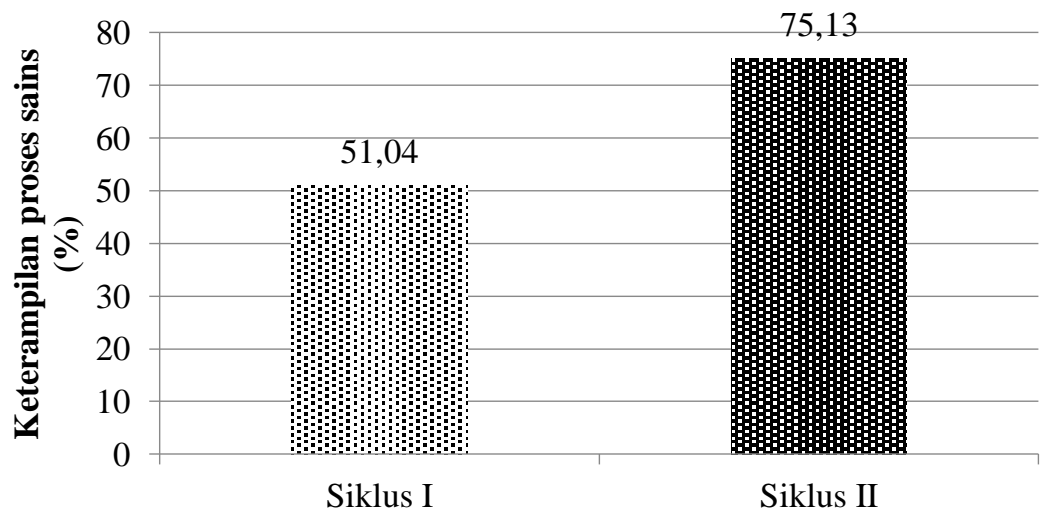

Gambar 2. Hasil Observasi KPS

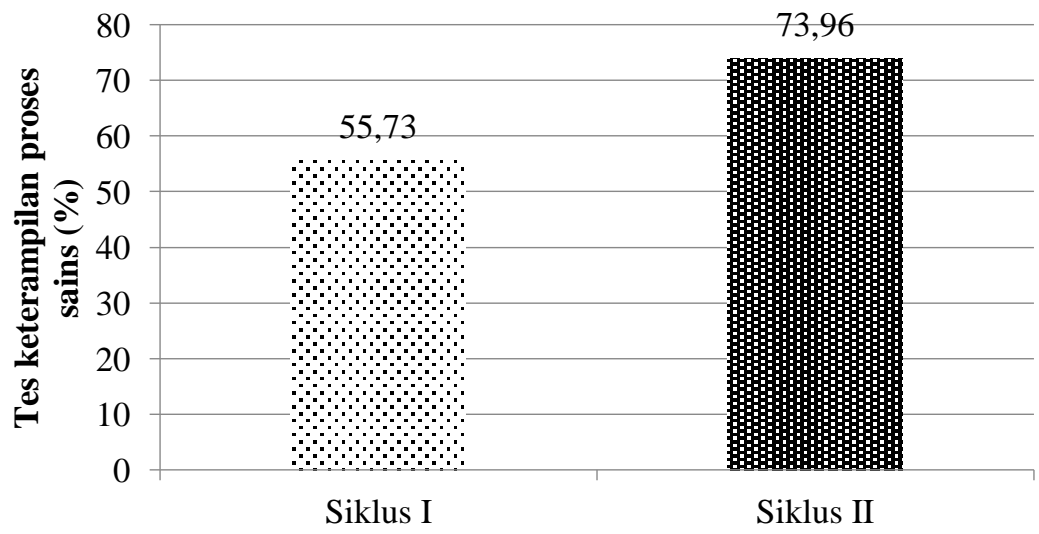

Gambar 3. Hasil Tes KPS

Hasil observasi KPS mengalami peningkatan dari 51,04\% dengan kategori cukup terampil menjadi 75,13\% dengan kategori terampil. Sedangkan hasil tes KPS dari $55,73 \%$ dengan kategori cukup terampil menjadi $73,96 \%$ dengan kategori terampil, sejalan dengan penelitian Latifah, Komikesari, dan Ulum (2017) Penerapan model pembelajaran REACT membuat peserta didik dapat mengembangkan KPS dengan baik.

KPS peserta didik mengalami peningkatan dikarenakan efektifknya bimbingan dari guru selama proses pembelajaran, dimulai dari mengamati, mengajukan pertanyaan, membuat hipotesis, menafsirkan data yang diperoleh 
kemudian menerapkan konsep dan mengkomunikasikannya. Tindakan ini dilakukan secara berulang-ulang hingga peserta didik terbiasa dengn jalannya pembelajaran.

\section{Analisis Hasil Belajar Peserta Didik}

Hasil belajar yang dimaksud adaIah hasil belajar kognitif peserta didik. Pada siklus 1l, pembelajaran bisa dikatakan berhasil karena persentase ketuntasan hasil belajar peserta didik mengalami peningkatan lebih dari 75\%. Adapun perbandingan ketuntasan hasil belajar peserta didik dapat dilihat pada Gambar 4.

Siklus I

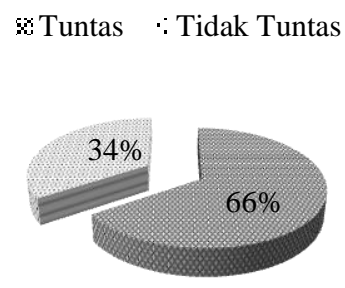

Siklus II

@ Tuntas $\because$ Tidak Tuntas

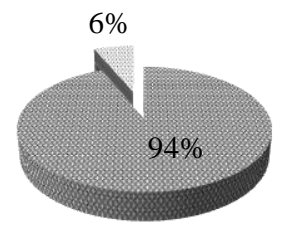

\section{Gambar 4. Perbandingan Hasil Belajar}

Pembelajaran siklus 1 dapat dikatakan beIum berhasiI dikarekan ketuntasan hasiI belajar peserta didik belum mencapai secara klasikal. Kemudian proses pembelajaran diperbaiki ditunjukkan dengan meningkatnya persentase perserta didik menjadi tuntas pada siklus II. Peningkatan hasil belajar peserta didik ini sejalan dengan penelitian Purnamasari, Masriani, \& Hadi, (2016) model pembelajaran REACT berpengaruh terhadap hasil belajar peserta didik pada materi kimia. HaI ini karena pembeIajaran konteksual adalah pembelajaran yang dapat mengembangkan level kognitif pesertadidik untuk berpikir kreatif daIam mengumpuIkan data, memahami suatu permasalahan dan memecahkan masalah.

\section{Respon Peserta Didik}

Pembelajaran menggunakan modelpembelajaran REACT memperoleh respon yangbaik dari semua pesertadidik. Gambaran Hasil respon pesertadidik terhadap pengunaan model pembelajaran REACT dapat dilihat pada Gambar 5.

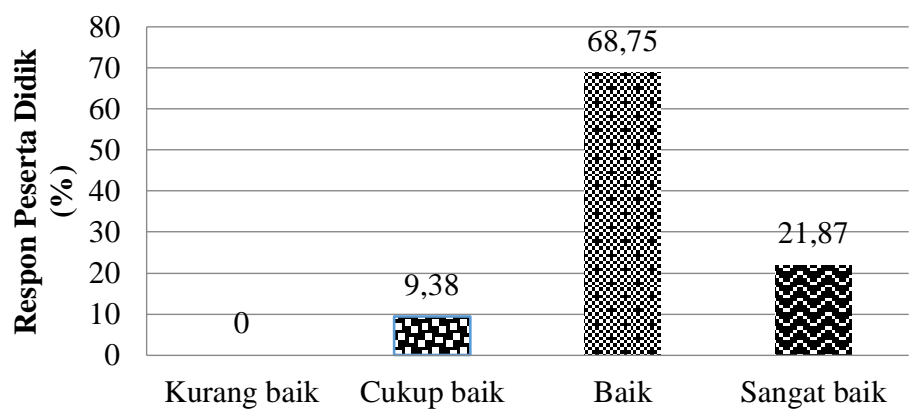

Gambar 5. Hasil Respon Peserta Didik 
Peserta didik menunjukkan respon yang positif terhadap penggunaan model pembeIajaran REACT selama proses pembeIajaran. Hal ini sejalan dengan penelitian dengan penelitian Farid \& Nurhayati (2014) dengan model pembelajaran REACT dapat menciptakan suasana pembelajaran yang menyenangkan karena penerapan model pembelajaran $R E A C T$ melibatkan peserta didik secara langsung untuk terlibat aktif dalam proses pembelajaran hal ini membuat perhatian peserta ddik dapat berpusat pada pembelajaran, lebih termotivasi untuk giat belajar karena merasa tertarik dengan pelajaran dan mempermudah peserta didik dalam memecahkan masalah sebab dalam model pembelajaran ini peserta didik dituntut untuk dapat memecahkan masalah secara mandri atau bekerjasama dengan kelompok.

\section{SIMPULAN}

Berdasarkan hasil penelitian terhadap peserta didik kelas XI IPA-1 SMA Negeri 10 Banjarmasin, dapat disimpulkan bahwa setiap tindakan dari modeI pembelajaran REACT yang digunakan berupa mengiatkan materi pembeIajaran dengan kehidupan sehari-hari peserta didik yang merupakan tahap relating, melaksanakan kegiatan eksperimen yang merupakan tahap experiencing, bekerja sama menyelesaikan permasalahan yang baru merupakan tahap dari applying dan cooperating serta pemberian tes yang merupakan tahap transferring. Tindakantindakan tersebut berhasil meningkatkan aktivitas guru, aktivitas peserta didik, keterampilan proses sains dan hasil belajar kognitif, serta peserta didik merespon positif terhadap pembelajaran.

\section{DAFTAR RUJUKAN}

Depdiknas. (2003). Model Penyelenggaraan Sekolah Kategori Mandiri /Sekolah Standar Nasional. Jakarta: Direktorat Pembinaan Sekolah Mengah Atas. Dirjen Manajemen Pendidikan Dasar dan Menengah.

Farid, A., \& Nurhayati, S. (2014). Pengaruh Penerapan Strategi REACT Terhadap Hasil Belajar Kimia Siswa Kelas XI A. Chemistry in Education, 3(1), 37-42.

Irwanto, Rohaeti, E., Widjajanti, E., \& Suyan. (2017). Students' science process skill and analytical thinking ability in chemistry learning. The 4th International Conference on Research, Implementation, and Education of Mathematics and Science, 1-4. doi:10.1063/1.4995100

Khasanah, U. (2017). Meningkatkan Keterampilan Proses Sains dan Hasil Belajar Menggunakan Model Inkuiri Terbimbing Pada Materi Laju Reaksi Siswa Kelas XI IPA 1 SMA Negeri 1 Banjarmasin Tahun Pelajaran 2016/2017. Skripsi Jurusan Pendidikan Kimia FKIP ULM. Banjarmasin: Tidak dipublikasi.

Latifah, S., Komikesari, H., \& Ulum, M. (2017). Efektivitas Strategi REACT (Relating, Experiencing, Applying, Cooperating, Transfering) Terhadap Hasil Belajar dan Keterampilan Proses Sains di SMP N 22 Bandar Lampung. Jurnal Penelitian Pembelajaran Fisika, 8(2), 101-108.

Lindawati, S. (2017). Peningkatan Aktivitas dan Hasil Belajar Matematika Melalui Strategi Pembelajaran REACT pada Siswa Kelas XI IPA3 SMAN Bernas Kabupaten Pelalawan. Indonesian Digital Journal of Mathematics and Education, 4(7), 410-420.

Marcelia, W., Margunayasa, \& Kusmariyatni. (2016). Pengaruh model POGIL dan minat belajar terhadap keterampilan proses sains pada siswa kelas V SD. EJournal PGSD Universitas Pendidikan Ganesha, 4, 1-9.

Meledy, K. J. (2015). Contextualized Learning. Institute for Completion-Research Brief(1), 1-4. 
Mutrovina, N., \& Syarief, S. H. (2015). Meningkatkan Keterampilan Proses Sains Siswa Melalui Penerapan Model Pembelajaran Inkuiri Terbimbing pada Materi Reaksi Reduksi-Oksidasi di Kelas X SMA Negeri 12 Surabaya. UNESA Journal of Chemical Education, 4(3), 466-471.

Norshofiati, Hamid, A., \& Bakti, I. (2017). Efektivitas Model Pembelajaran Cooperative Script Dikombinasikan dengan Model Tps Terhadap Kemampuan Kritis Siswa Pada Materi Koloid Kelas XI IPA SMA Negeri 12 Banjarmasin. Journal of Chemistry And Education (JCAE), 1(1), 93-103.

Purnamasari, E., Masriani, \& Hadi, L. (2016). Pengaruh Model REACT Terhadap Hasil Belajar Siswa SMA Negeri 1 Sungai Ambawang. Jurnal Pendidikan dan Pembelajaran, 5(11), 1-10. 